\title{
Patterns of settlement and growth of juvenile flounder Rhombosolea tapirina determined from otolith microstructure
}

\author{
Helen M. A. May, Greg P. Jenkins \\ Department of Zoology and Victorian Institute of Marine Sciences, University of Melbourne, Parkville, Victoria 3052, Australia
}

\begin{abstract}
Otolith microstructure was used to examine settlement and growth of juvenile Rhombosolea tapirina Günther from a site within Swan Bay, Victoria, Australia. A distinct transition zone on sagittae coincides with settlement from the pelagic larval phase to the benthic juvenile habitat. The daily settlement pattern was reconstructed using otolith increments from fish collected during and at the end of the settlement season. Settlement was continuous from July to October. However, most individuals had apparently immigrated from other settlement areas or were inaccessible to sampling for a brief period after settlement. The settlement pattern persisted over time, however, peaks were no longer evident at the end of the settlement season. The population growth rate of juvenile flounder was found to be approximately linear over the size range sampled, averaging $0.29 \mathrm{~mm} \mathrm{~d}^{-1}$. A significant linear relationship between standard length and otolith radius allowed back-calculation of individual growth trajectories for a 'winter' and a 'spring' cohort. Significant differences were found in growth trajectories for each cohort; growth rate over the first $20 \mathrm{~d}$ post settlement for the winter cohort averaged approximately $0.17 \mathrm{~mm} \mathrm{~d}^{-1}$ compared to $0.23 \mathrm{~mm} \mathrm{~d}^{-1}$ for the spring cohort. The relationship between daily growth and air temperature was compared using cross correlation. Cross correlation functions showed a significant positive correlation at lags of 2 to $5 \mathrm{~d}$ for the winter cohort and a significant negative correlation at a lag of $1 \mathrm{~d}$ for the spring cohort. This suggests that early in the settlement season, temperature had a positive influence on metabolism, which in turn affected somatic and otolith growth rates. However, temperature apparently reached a critical level later in the season, which resulted in high temperature having a deleterious effect on metabolism, leading to a negative correlation between temperature and growth.
\end{abstract}

\section{INTRODUCTION}

For fish that have a distinct metamorphosis from a planktonic larval form to a benthic juvenile, the patterns of spawning, larval dispersal, larval mortality and habitat selection will eventually be observed in settlement patterns (Keough \& Downes 1982, Doherty \& Williams 1988). These patterns will be further modified by mortality in the juvenile stage. One factor in the mortality of larval and juvenile fish that may be of critical importance is growth rate. Smith (1985) suggested that the growth rates of late larval and early juvenile fish may affect the magnitude of recruitment because they determine the duration of the most vulnerable stages. Therefore, accurate estimation of growth rates of juvenile fish collected from the field, and the evaluation of factors which may influence growth, is a necessary prerequisite to understanding mortality in juvenile fish.

Studies of growth and settlement patterns have been greatly facilitated by Panella's (1971) discovery of daily growth increments in otoliths of juvenile fish. Daily increments in otoliths have now been validated for a large number of marine and freshwater fish (Campana \& Neilson 1985, Jones 1986). Because larvae and juveniles can be aged, growth rates can be determined for populations from size at age. Moreover, where there is a smooth monotonic relationship between otolith size and fish size, growth trajectories of individuals can be determined by backcalculating size from the radius to daily increments (Jenkins \& Davis 1990). Furthermore, changes in increment morphology 
often occur at times of ecological and physiological transitions in development (Brothers \& McFarland 1981). Such a transition often occurs at the end of the larval stage, with a characteristic change in increment spacing and contrast. These 'settlement marks' allow settlement dates to be accurately determined and settlement patterns to be reconstructed.

Rhombosolea tapirina Günther is a commercially important pleuronectid in southern Australia (Hutchings \& Swainston 1986). Daily periodicity of increment formation in juvenile $R$. tapirina has been validated under the assumption that stress marks on otoliths were formed due to handling and immersion in tetracycline (Stewart \& Jenkins 1991). In the present study we analyse daily increments in otoliths of juvenile $R$. tapirina to determine settlement patterns and juvenile growth histories. Settlement patterns of fish collected throughout the breeding season are compared with those recorded in otoliths from fish collected at the end of the breeding season to determine if patterns were preserved in the population structure. We also construct detailed growth histories of 2 cohorts of fish settling at different times to estimate growth rates and trajectories, and to determine the effect of temperature on growth.

\section{MATERIALS AND METHODS}

Field sampling. Rhombosolea tapirina juveniles were collected between September and November 1989 from Swan Bay, Queenscliff (Fig. 1). Collections were made with a beach seine net $(10 \mathrm{~m} \times 1.5 \mathrm{~m}$, mesh size $1 \mathrm{~mm}$ ) hauled parallel and adjacent to the shore for $20 \mathrm{~m}$; the net was hauled between 2 and 6 times to provide an adequate sample. Metamorphosing larvae were collected from nearby sites in Swan Bay and Port Phillip Bay (Fig. 1) on 27 September and 4 October 1990. Larvae were collected with a $0.64 \mathrm{~m}^{2}$ opening, $1 \mathrm{~mm}$ mesh plankton net, towed at the surface for $10 \mathrm{~min}$. Larvae and juveniles were immediately anaesthetized in MS 222 and then preserved in 95\% ethanol. We assumed that any shrinkage in preservative was a relatively constant proportion over the size range analysed and therefore would have a minimal affect on growth rate estimates.

Otolith preparation. The standard length (SL) of specimens was determined by measuring from the snout to the caudal peduncle, to the nearest $0.1 \mathrm{~mm}$, under a dissecting microscope with an ocular micrometer. Specimens were placed in a drop of water on a microscope slide and the utricular (lapilli) and saccular (sagittae) otoliths were dissected out using electrolytically-sharpened tungsten probes (or forceps, when the fish were greater than $20 \mathrm{~mm} \mathrm{SL}$ ). Contrast between
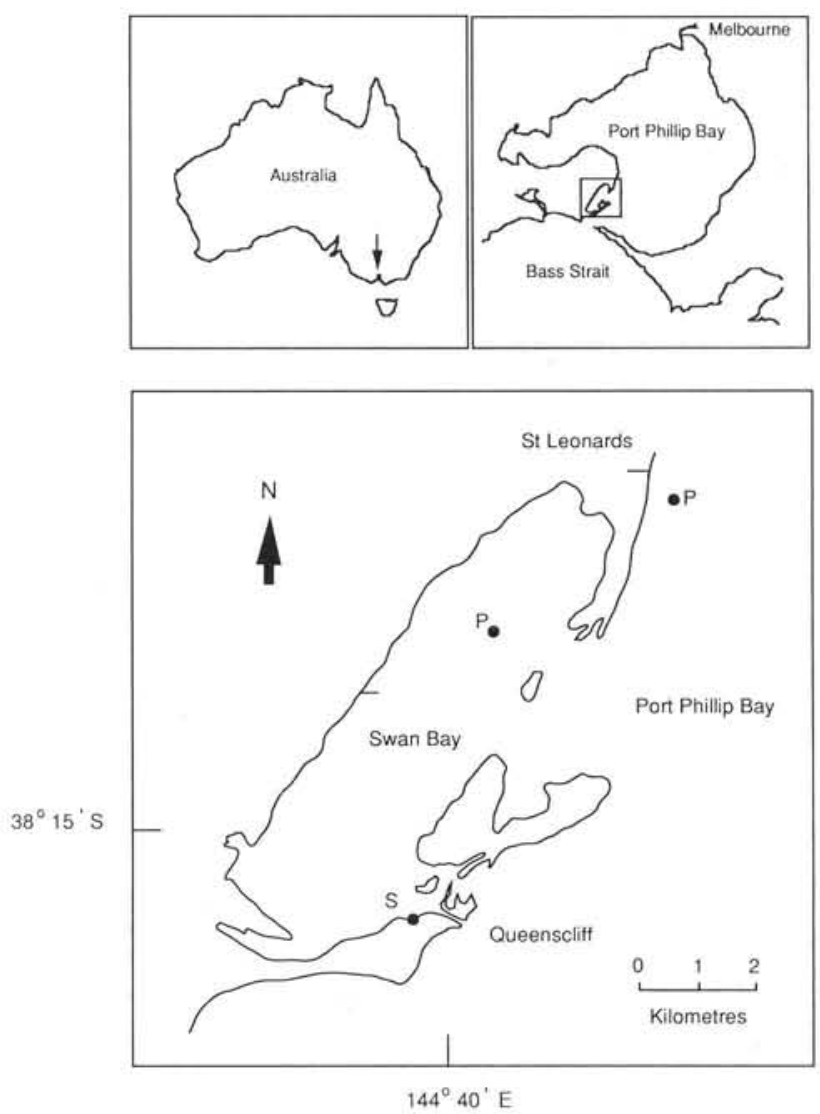

Fig. 1. Location of sampling sites in Swan Bay and Port Phillip Bay, Victoria, from which larval and juvenile flounder were collected. Insets: Location of Swan Bay in Port Phillip Bay and location of Port Phillip Bay on the Victorian coast. S: seining; P: plankton sampling

the otoliths and surrounding tissue was maximised by using a polarizing light source fitted to the stereo microscope. The otoliths were left to dry, flat side up, and then placed in immersion oil on glass slides.

Otoliths that could be read without further preparation were mounted permanently in Gurr's neutral mounting medium, with fine nylon monofilament on either side to prevent crushing by the cover slip. Otoliths that required grinding and polishing (fish greater than $18 \mathrm{~mm} \mathrm{SL}$ ) were cleaned with alcohol and then mounted, flat side up, in epoxy resin. Otoliths were manually ground with a succession of 600 up to 1200 grade wet and dry sandpaper until the otolith surface was reached. They were then polished with $6 \mu \mathrm{m}$ diamond paste on a lapping machine. The lapping machine ensured that otoliths were polished on a horizontal plane.

Otolith analysis. Otolith measurements and counts were made with a compound microscope. A video camera connected to the microscope produced an image which was displayed and digitised on a Com- 
modore 'Amiga' computer. Specimens were examined randomly and blindly with respect to SL. Otoliths from larvae were examined for the presence or absence of a transition zone associated with metamorphosis.

The otolith radius was measured for all fish sampled up to $40 \mathrm{~mm}$, and radius to each increment was measured for 50 specimens to determine incremental widths. The radius was measured along the line of maximum otolith radius.

We attempted to count the post-settlement increments on all 4 otoliths. Post-settlement increments were defined as those deposited after the transition zone of poorly-defined increments which has previously been observed at the edge of otoliths of immediate pre-settlement flounder collected in the plankton (Jenkins 1987). A clarity value for increments was assigned in the range of 1 to $4 ; 1$ representing low clarity and 4 representing the clearest. Only readings having a clarity of greater than 2 were accepted. When the increment count for otoliths from the same fish differed by 2 or more the data were discarded. Usable data were obtained from $94 \%$ of the fish examined, and the mean count for each fish was analysed.
All statistical analyses were conducted using the 'SYSTAT' computer programs (Wilkinson 1987). Assumptions for parametric analyses were examined using box plots and the distribution of residuals.

\section{RESULTS}

\section{Otolith examination}

Daily increments were clearly visible on the sagittae until the fish were approximately $20 \mathrm{~mm}$ SL (Fig. 2). Sagittae from fish greater than $20 \mathrm{~mm}$ in length were ground and polished, which improved the visibility of the growth increments. The number of increments counted on the sagittae were consistent with unground lapilli, which were relatively smaller and more transparent (Fig. 3). Widths of daily increments in sagittae ranged from approximately 0.8 to $7.7 \mu \mathrm{m}$.

A change in the morphology of increments was observed at approximately $60 \mu \mathrm{m}$ from the primordium in the sagittae (Fig. 2), and $20 \mu \mathrm{m}$ from the primordium in the lapilli (Fig. 3). The width of the increments

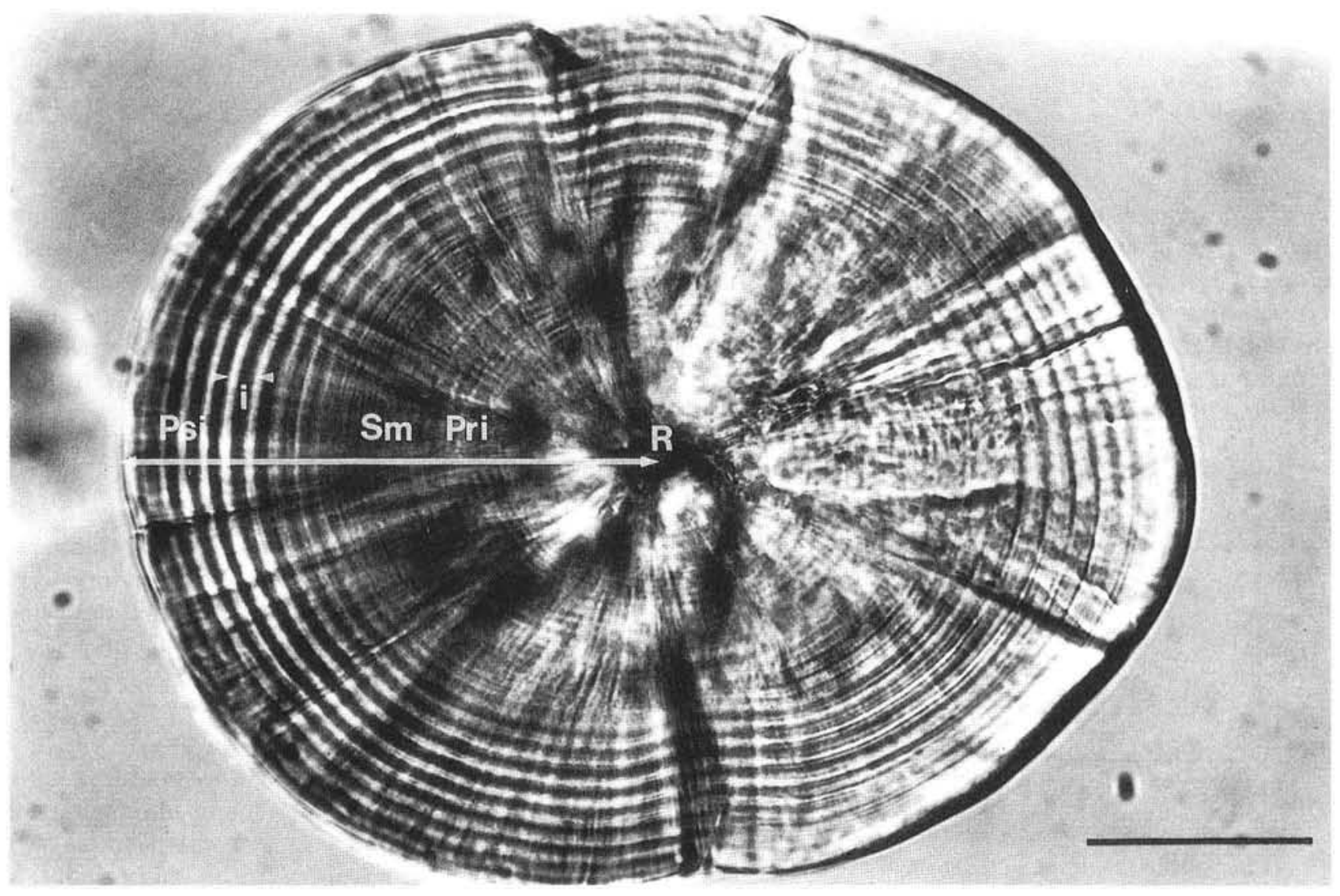

Fig. 2. Rhombosolea tapirina. Photomicrograph of a sagitta with 9 post settlement increments, dissected from a $6.8 \mathrm{~mm}$ juvenile flounder. Growth increments (i) appear as pairs of light (calcium-rich) and dark (protein-rich) bands; Sm: settlement mark; Psi: post settlement increments; Pri: pre settlement increments; R: radius for measurement. Scale bar $=40 \mu \mathrm{m}$ 


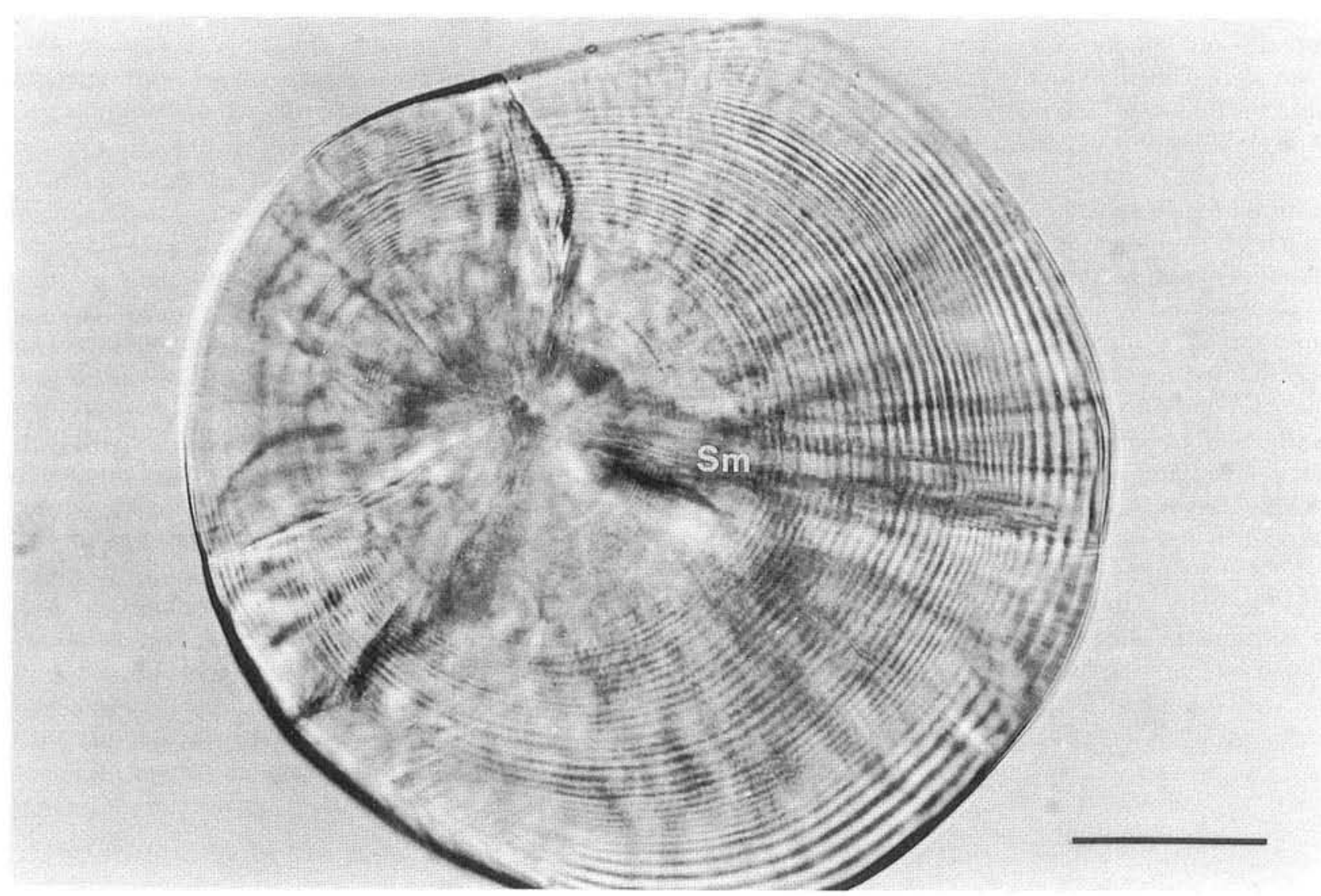

Fig. 3. Rhombosolea tapirina. Photomicrograph of a lapillus with 34 post settlement increments, dissected from a $13.2 \mathrm{~mm}$ juvenile flounder. Sm: settlement mark. Scale bar $=20 \mu \mathrm{m}$

increased from the primordium, then became indistinct, and then clear increments resumed, however the increment width was usually different. In some lapilli there was no indistinct zone, however there was a transition in increment width. Sagittae from 12 metamorphosing (Stages 4 \& 5, Ryland 1966) larvae col-

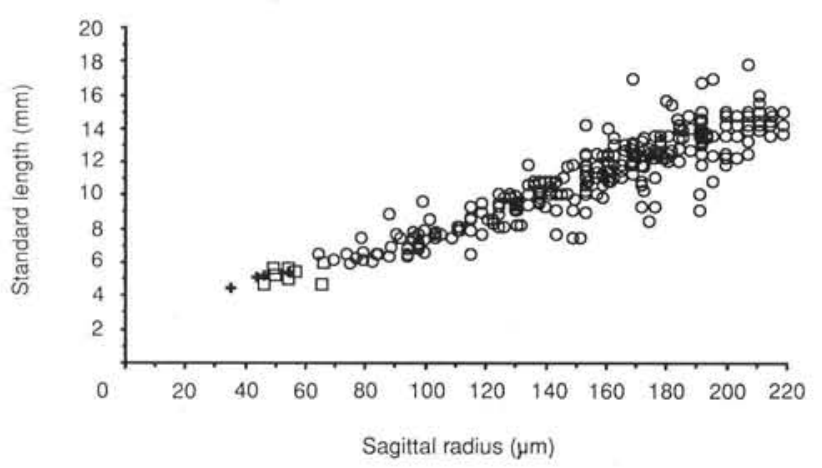

Fig. 4. Rhombosolea tapirina. Relationship between sagittal radius and standard length for juvenile flounder. Regression equation for juvenile stage: $Y=0.064 X+1.162, \mathrm{r}^{2}=0.72$. (O) juveniles; (+) larvae; ( $\square$ ) metamorphosing (Stage 5) larvae with the transition zone evident at the edge of the otolith lected from Swan Bay and Port Phillip Bay contained larval rings, and in the most developed specimens (Stage $5, \mathrm{n}=8$ ), various stages of development of the transition zone, confirming the results for metamorphosing larvae collected in Port Phillip Bay by Jenkins (1987). Otoliths from metamorphosing larvae in both studies did not contain daily increments exterior to the transition zone. The maximum radius of sagittae from metamorphosing larvae was approximately equal to the minimum radius of sagittae from settled juveniles (Fig. 4). From this evidence we assume that the number of increments exterior to the transition zone approximates the number of days since completion of metamorphosis and settlement.

\section{Settlement patterns}

The settlement date of each fish was determined by subtracting the number of increments after settlement from the date of capture. Settlement histories were constructed from fish up to $80 \mathrm{~d}$ post-settlement for fish caught throughout the settlement period, and for fish up to $130 \mathrm{~d}$ post-settlement for those collected at the end of the settlement period. 
To determine when the settlement season began, the settlement pattern was constructed for fish caught on 6 September, using fish which had up to 80 post-settlement increments. Back-calculation of settlement dates suggests that the first settlement event occurred on 22 June (Fig. 5). The settlement pattern constructed from fish up to $20 \mathrm{~mm}$ (40 d post-settlement) collected during the settlement period showed that settlement was continuous throughout this period (Fig. 6).

There appeared to be a significant gap between the date of each collection and the date that an individual most recently settled; only a few individuals were caught which had fewer than about 10 postsettlement increments (Fig. 6). However, individuals which had settled over this period of about $10 \mathrm{~d}$ were present on the next date of collection. For example, fish collected on 6 and 12 September included no individuals which had settled between 30 August and 5 September, however fish which had settled over this period were collected on 16 September (Fig. 6). This phenomenon was repeated on later sampling dates.

The settlement pattern revealed by combining the settlement patterns from each capture date showed relatively continuous settlement, with a possible separation of 2 broad modes at approximately julian day 235 (Fig. 7A). The settlement pattern reconstructed for fish caught on 14 November and 7 December (Fig. 7B) mirrored the relatively continuous settlement evident during the settlement period (Fig. 7A), however, the 2 major single day peaks, on 13 August and 13 September, were no longer present. Settlement dates calculated for fish collected on 7 December suggests that settlement ceased around 9 October (Fig. 7B).

\section{Overall growth}

Standard length was plotted against the number of days since settlement for a total of 495 fish from all sampling dates. The relationship was approximately linear over the size range sampled (Fig. 8), linear regression of total length against age was significant (n $=487, F=11397.29, \mathrm{p}<0.001$ ) and yielded the equation:

$\mathrm{SL}=0.29 \mathrm{D}+3.62\left(\mathrm{r}^{2}=0.96 ; \mathrm{D}=\right.$ days post-settlement $)$

This suggests an overall growth rate of approximately $0.29 \mathrm{~mm} \mathrm{~d}^{-1}$. Although the overall linear regression explains a large proportion of the variance in the data, there is a noticeable inflection in the data at approximately $40 \mathrm{~d}$ post-settlement. Data for fish less than $40 \mathrm{~d}$ post-settlement were mainly derived from specimens collected during the settlement season while data for fish greater than $40 \mathrm{~d}$ post-settlement were mainly derived from fish collected at the end of the settlement season. The linear regression for fish less than or equal to $40 \mathrm{~d}$ post-settlement $(\mathrm{n}=328, F=880.21, \mathrm{p}<0.001$ ) yielded the equation:

$$
\mathrm{SL}=0.23 \mathrm{D}+5.11\left(\mathrm{r}^{2}=0.73\right)
$$

This may be compared with the regression for fish greater than $40 \mathrm{~d}$ post-settlement $(\mathrm{n}=159, F=1664.73$, $\mathrm{p}<0.001$ ):

$$
\mathrm{SL}=0.31 \mathrm{D}+1.82\left(\mathrm{r}^{2}=0.91\right)
$$

\section{Standard length as a function of otolith radius}

A linear regression between sagittal radius and fish size for juvenile Rhombosolea tapirina up to $20 \mathrm{~mm}$ SL was significant $(\mathrm{n}=253, F=653.48$, $\mathrm{p}<0.001$ ), indicating that fish and otolith size were directly related (Fig. 4). During metamorphosis otoliths continued to grow while growth in length ceased. The smallest post-settlement individuals appeared to be still in the stage of minimal growth in length (Fig. 4).

The relationship between standard length and sagittal radius for juvenile Rhombosolea tapirina was
Fig. 5. Rhombosolea tapirina. The settlement pattern of juvenile flounder collected on 6 Sep 1989, reconstructed by back-calculation using daily increments

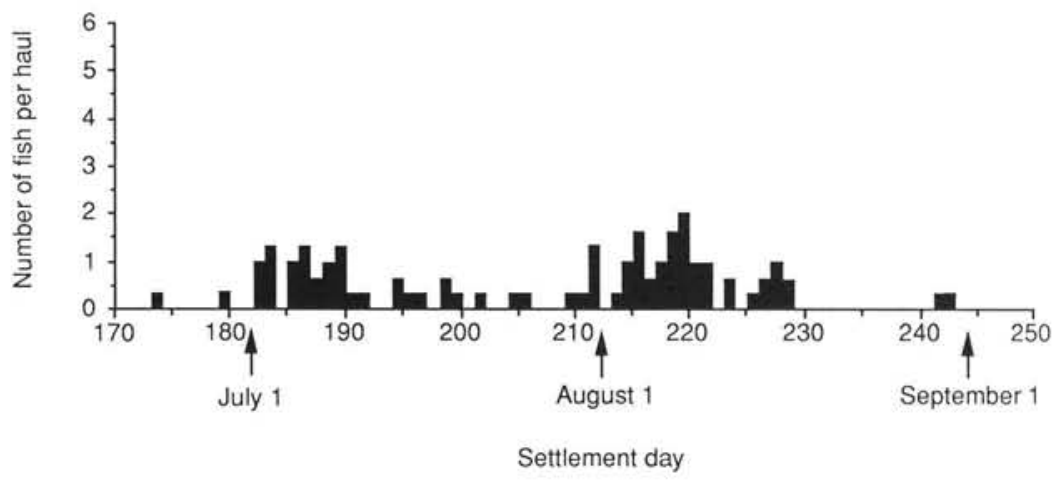




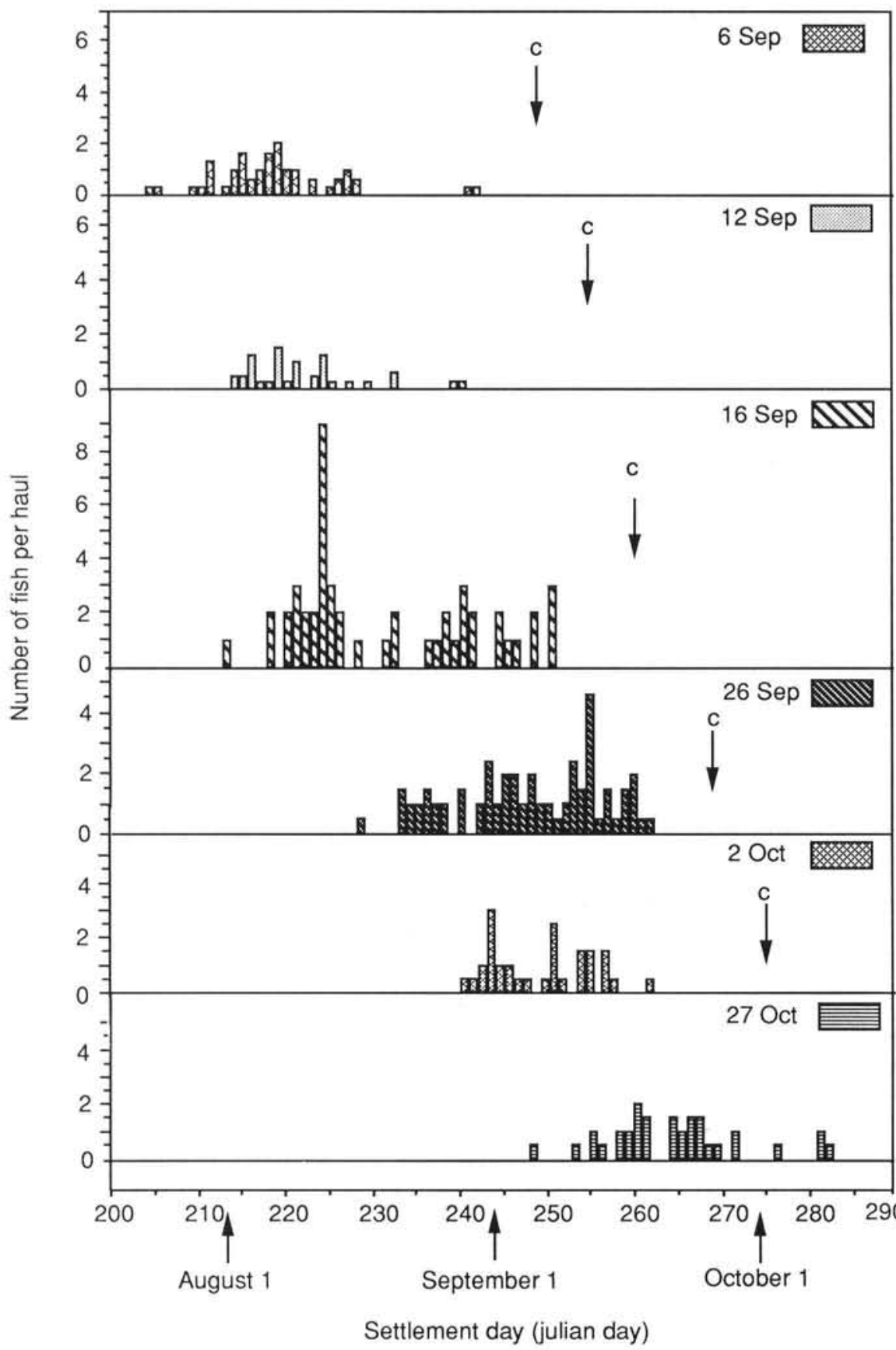

Fig. 6. Rhombosolea tapirina. Settlement pattern of juvenile flounder less than $20 \mathrm{~mm}$ SL collected throughout the breeding season, reconstructed by backcalculation from daily increments. c: collection date

examined for 2 cohorts encompassing peaks of settlement ('winter': julian days 220 to 230 ; 'spring': julian days 253 to 265). The linear regression for each cohort was significant (winter cohort: $\mathrm{n}=58, F=333.1$, $\mathrm{p}<0.001$; spring cohort: $\mathrm{n}=54, F=295.8, \mathrm{p}<0.001)$ (Fig. 9). Analysis of covariance (ANCOVA) was used to assess differences in the relationship between SL and otolith radius between cohorts. To ensure the ranges of the covariate for the 2 cohorts were the same for the analysis of covariance, only juveniles which had an otolith radius between 100 and $220 \mu$ m were used. The regression lines were not significantly different between the cohorts (Table 1).

\section{Back-calculated growth trajectory}

The demonstration of a direct relationship between otolith radius and fish standard length allows the individual growth trajectories of fish in each cohort to be determined. Successive increment radii for fish from each cohort were measured. These fish had a range of 20 to 40 post-settlement increments. The standard 
Fig. 7. Rhombosolea tapirina. The pattern of settlement of juvenile flounder collected at (A) 6 intervals over the settlement season, and (B) from fish collected at the end of the settlement season, reconstructed from daily increments. C: collection date. Key to shading as for Fig. 6

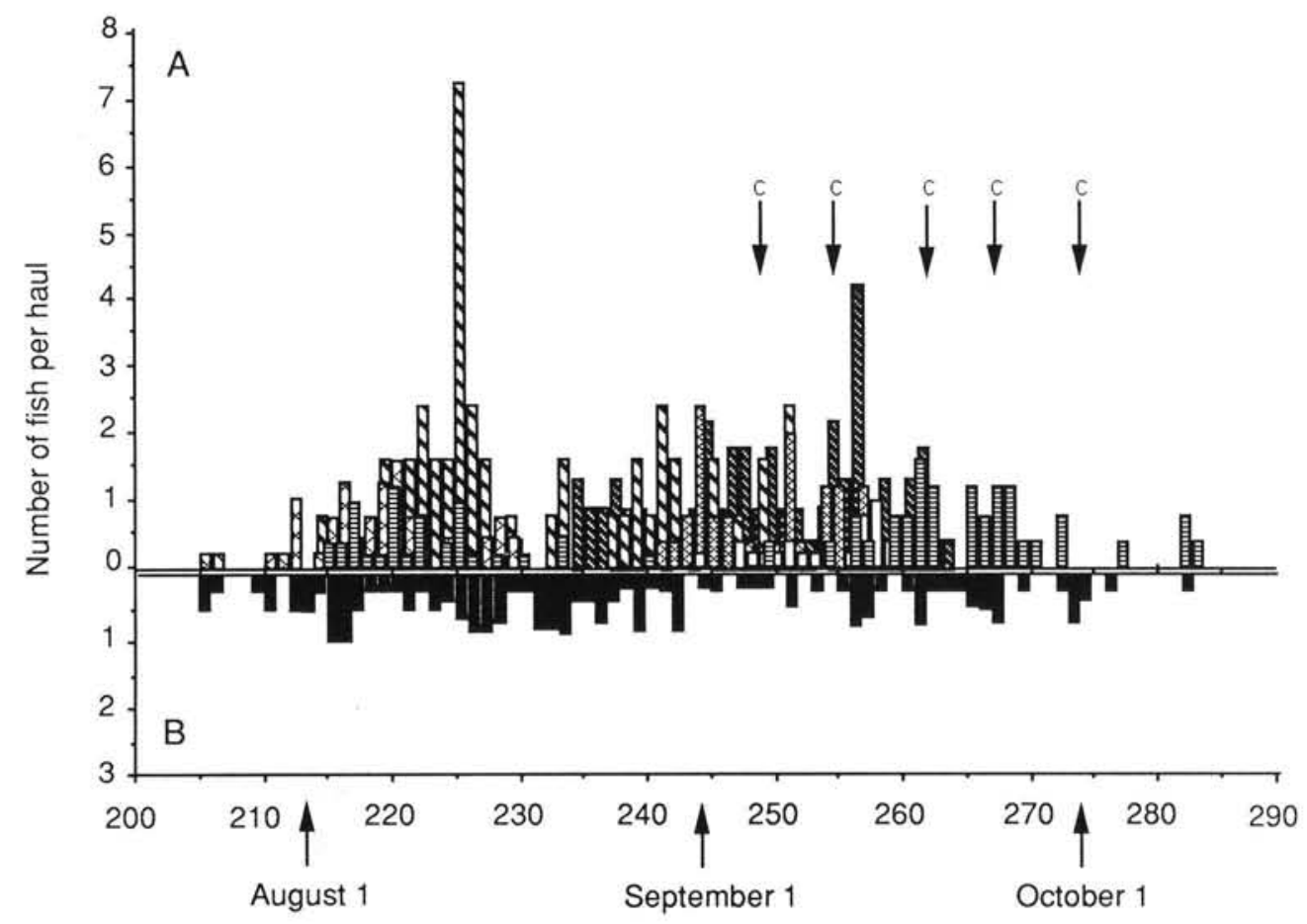

Settlement day (julian day)

length of fish from each cohort was derived from the corresponding otolith radius by the pooled regression equation:

$$
\mathrm{SL}=0.065 \mathrm{R}+0.95\left(\mathrm{r}^{2}=0.87 ; \mathrm{R}=\text { sagittal radius }\right)
$$

The growth trajectories for each cohort are shown in Fig. 10. Growth trajectories of the 2 cohorts were approximately linear. Fish from the winter cohort initially grew at a slower rate than those from the spring cohort, however after approximately the 20th post-settlement increment fish from the 2 cohorts grew at about the same rate. This trend is confirmed

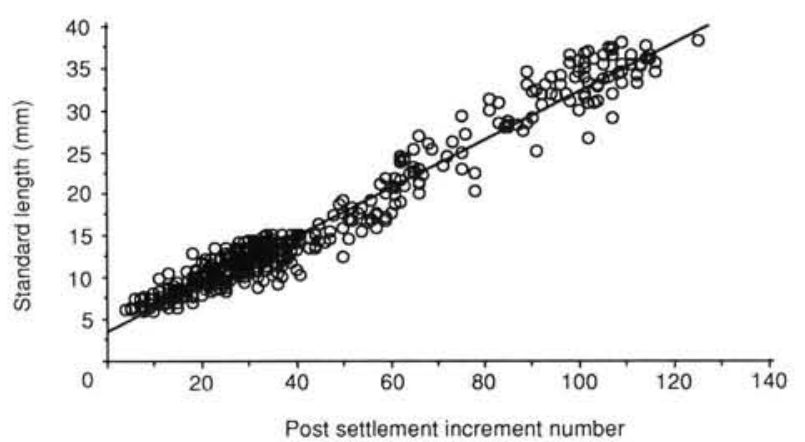

Fig. 8. Rhombosolea tapirina. Standard length and number of post settlement increments of juvenile flounder, with fitted regression line when increment widths are examined for the 2 cohorts. Because otolith increment widths are a repeated measure, multivariate repeated measures analysis was used to determine if there were any differences between growth rates of fish from the 2 cohorts for the first $20 \mathrm{~d}$ after settlement. There was no significant interaction between increment width and cohort and differences among increment widths within cohorts were (marginally) non-significant, however increment widths were significantly different between cohorts (Table 2). In terms of standard length, growth rate of the winter cohort was approximately $0.17 \mathrm{~mm} \mathrm{~d}^{-1}$ for the first $20 \mathrm{~d}$ and then

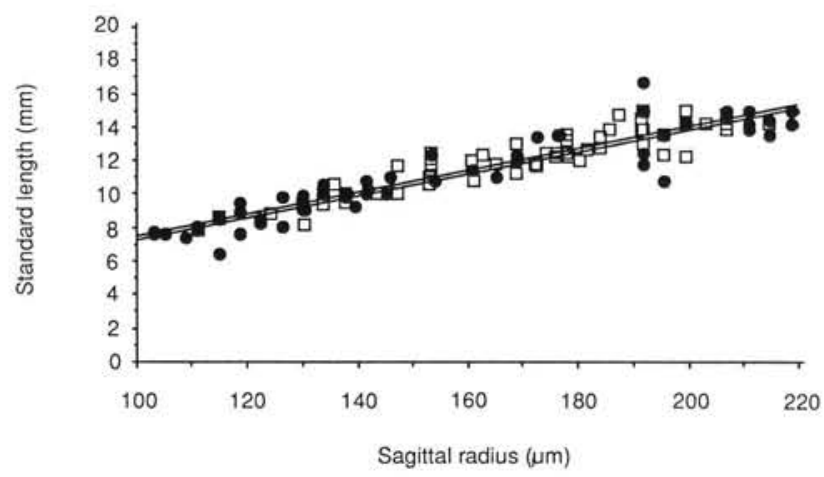

Fig. 9. Rhombosolea tapirina. Standard length and sagittal radius for juvenile flounder, with fitted regression lines. (ㅁ) 'Winter' cohort; (•) 'spring' cohort 
Table 1. Rhombosolea tapirina. Analysis of covariance comparing the growth of 2 cohorts of juvenile flounder using otolith radius as the covariate

\begin{tabular}{|lccccc|}
\hline Source & $\begin{array}{c}\text { Sum of } \\
\text { squares }\end{array}$ & df & $\begin{array}{c}\text { Mean } \\
\text { square }\end{array}$ & F-ratio & $\mathrm{p}$ \\
\hline Cohort & 0.005 & 1 & 0.005 & 0.007 & 0.935 \\
Radius & 432.536 & 1 & 432.536 & 621.880 & 0.000 \\
Cohort $\times$ & 0.009 & 1 & 0.009 & 0.013 & 0.910 \\
Radius & 75.117 & 108 & 0.696 & & \\
Error & 0.743 & 1 & 0.743 & 1.077 & 0.302 \\
\hline Cohort & 463.468 & 1 & 463.468 & 672.443 & 0.000 \\
Radius & 75.126 & 109 & 0.689 & & \\
Error & & & & & \\
\hline
\end{tabular}

Table 2. Rhombosolea tapirina. Multivariate repeated measures analysis comparing increment widths over 20 d postsettlement, for 2 cohorts of juveniles

\begin{tabular}{|lrrrrc|}
\hline Source & & Pillai trace & F-statistic & df & p \\
\hline Cohort $\times$ Width & 0.475 & 1.238 & 19,26 & 0.30 \\
Width & & 0.589 & 1.962 & 19,26 & 0.05 \\
Source & SS & df & MS & F & p \\
\hline Cohort & 176.706 & 1 & 176.706 & 53.198 & $<0.001$ \\
Error & 146.154 & 44 & 3.322 & & \\
\hline
\end{tabular}

increased and became highly variable (Fig. 11). Fish in the spring cohort grew at a rate of approximately $0.23 \mathrm{~mm} \mathrm{~d}^{-1}$ for the first $20 \mathrm{~d}$ and were also highly variable thereafter.

\section{Temperature and growth}

To determine if temperature influenced the growth rate, a cross correlation between daily growth in standard length and temperature was applied using fish from the winter cohort (settlement on 12, 13 August) and the spring cohort (settlement on 15, 16 September). Daily water temperature measurements were unavailable but water temperature should be highly correlated with air temperature because juvenile flounder live in a very shallow habitat. The maximum daily air temperature at Geelong $(25 \mathrm{~km}$ from Swan Bay) was therefore used. The air temperature generally increased until day 265 and then fluctuated around a fairly constant level (Fig. 12A). A plot of the mean daily growth in standard length and its standard deviation over $1 \mathrm{~d}$ intervals for the 2 cohorts is shown in Fig. 12B. Standard length increments increased until about julian day 260 , and then remained at this level until julian day 270 , followed by a gradual

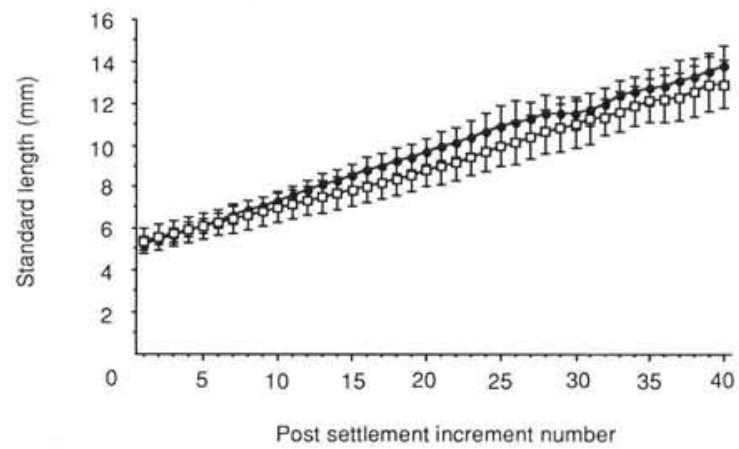

Fig. 10. Rhombosolea tapirina. Back-calculated standard length at age for juvenile flounder up to $40 \mathrm{~d}$ post settlement.

(ㅁ) 'Winter' cohort; $(\bullet)$ 'spring' cohort

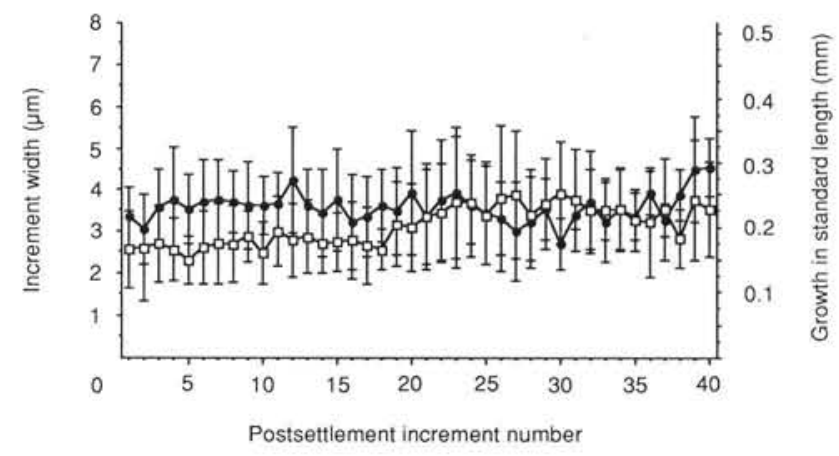

Fig. 11. Rhombosolea tapirina. Increment width and corresponding back-calculated increase in standard length in relation to post settlement increment number. (ㅁ) 'Winter' cohort; $(\bullet)$ 'spring' cohort. Error bars = $1 \mathrm{SD}$

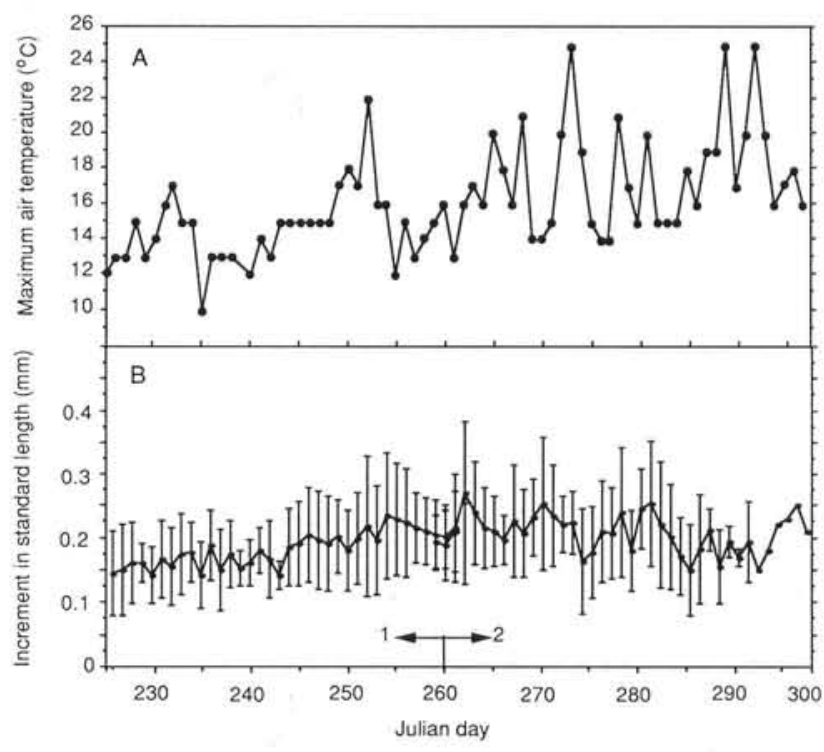

Fig. 12. Rhombosolea tapirina. Time series of (A) maximum air temperature and (B) daily increase in standard length of juvenile flounder settling on (1) 12, 13 August and (2) 15, 16 September 


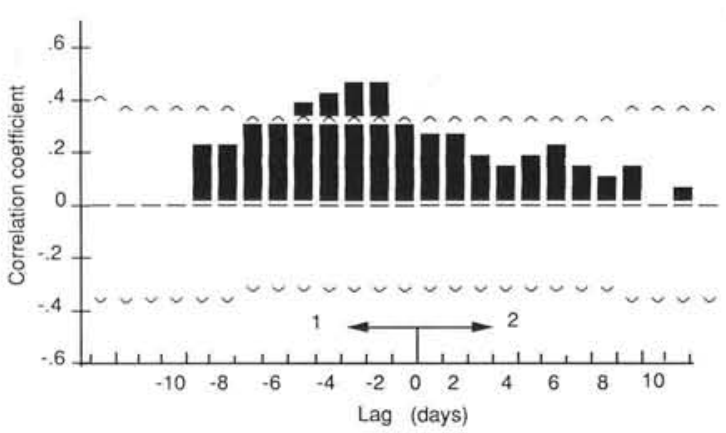

B

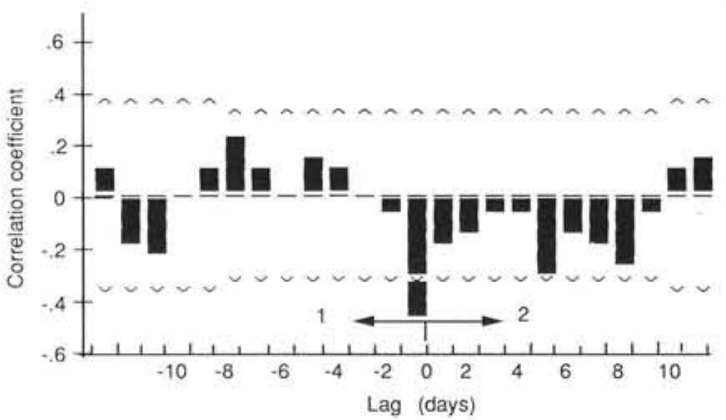

Fig. 13. Rhombosolea tapirina. Pattern of the estimated cross correlation between maximum air temperature and daily increase in standard length for (A) 'winter' cohort and (B) 'spring' cohort; (1) standard length series lagged behind maximum water temperature series; (2) water temperature series lagged behind standard length series; semicircles represent approximate significance limits ( 2 standard errors from zero)

decline. The time and growth series were differenced once to remove trend. The cross correlation function for the winter cohort indicated significant correlation at lags of 2 to $5 \mathrm{~d}$ of growth behind temperature. Correlation was maximal at a lag of 2 and $3 \mathrm{~d}$ and gradually diminished thereafter (Fig. 13). No significant correlation was found when temperature was lagged behind growth. The standard length increment series for the spring cohort was significantly negatively correlated at a lag of $1 \mathrm{~d}$ behind temperature (Fig. 13). No significant correlation was found when temperature was lagged behind growth.

\section{DISCUSSION}

\section{Otolith analysis}

The discontinuity evident in the sagittae of Rhombosolea tapirina apparently formed during the period of metamorphosis and settlement. Jenkins (1987) noted a change in increment morphology of larval $R$. tapirina at approximately 28 to $30 \mathrm{~d}$ after hatching, at the stage of notochord flexion when fin rays were forming and the eye had migrated to the edge of the head (Stage 5 of Ryland 1966). Increments at this point became wider, very faint and often indiscernible. Morphologically, the transition zone is similar to that described for Halichoeres bivittatus (Victor 1983), which is formed during metamorphosis when larvae are buried in sand. In the case of $R$. tapirina, the transition is present in metamorphosing larvae in the plankton. This is a stage of radical change in morphology, physiology and ecology in flounder. The ecological change is considerable; pelagic larvae occur in deeper waters (Crawford 1984, Jenkins 1986) while juveniles inhabit shallow intertidal habitats. The process of settlement would involve change in temperature, food availability and light, all of which are known to alter the microstructure of flounder otoliths (Berghahn \& Karakiri 1990).

Campana (1984) found that there was no evidence of metamorphosis in the sagittae of post-metamorphic flounder Platichthys stellatus reared in the laboratory. The microstructure of otoliths of wild juvenile flounder was characterized by the presence of a transition zone which may have formed at metamorphosis. The transition zone separated 2 distinct incremental sequences (inner and outer) which differed in both increment width and appearance. Campana (1984) suggested that physiological change during metamorphosis was insufficient to radically change the otolith microstructure. In the case of Rhombosolea tapirina, there was a relatively wide zone of indistinct increments, rather than simply a change in increment characteristics. Formation of this zone in larvae collected from the plankton suggests that there may be a physiological rather than ecological cause. However, ecological change may also be occurring at this stage; for example, metamorphosing plaice larvae alternate between planktonic and benthic habitats while migrating to juvenile nursery areas (Rijnsdorp et al. 1985). Transition zones similar to those in sagittae were evident in some lapilli, however in others the transition was simply one between increment sequences of different widths, similar to that described by Campana (1984).

\section{Settlement patterns}

The first settlement event recorded for Rhombosolea tapirina in Swan Bay occurred in late June and the last occurred in late October. Crawford (1984) found that sexual maturity indices for $R$. tapirina indicated prolonged spawning from June to October while Kurth (1957) found that they spawn from March to October and suggested that a water temperature below $13{ }^{\circ} \mathrm{C}$ is critical to the initiation of spawning. Larvae were collected in Port Phillip Bay from April to September (Jenkins 1986). 
The settlement pattern suggests that settlement is relatively continuous. This pattern could arise from continuous spawning, or from discontinuous spawning with a variable duration of larval life. Daily rings could be counted up to $35 \mathrm{~d}$ from hatching in Rhombosolea larvae (Jenkins 1987), however larvae older than approximately $35 \mathrm{~d}$ age could not be aged; increments were either not formed, or became indiscernible with the light microscope (Campana et al. 1987), at this stage. Larvae at this stage were at an advanced stage of metamorphosis. We therefore cannot assess the extent of variability in duration of the larval stage, so variability in the duration of the pre-settlement phase cannot be excluded as an explanation for continuous settlement. Continuous settlement is in contrast with results for many reef fish species (Doherty \& Williams 1988) which show strongly pulsed recruitment within breeding seasons.

The noticeable gap between the dates of capture and the back-calculated date of settlement suggests that fish of this age (less than approximately $10 \mathrm{~d}$ postsettlement) were either not in the sampling area or were inaccessible to the fishing gear. Although the latter cannot be fully discounted, the former possibility is most likely because immediate post-settlement flounder have been collected at other sites using the same net (Thompson 1990). The fact that the fish were collected on later sampling dates indicates that settlement was occurring during these times but not at the sampling site. This may be due either to larvae settling in deeper water, or moving horizontally along the shore. The latter is more likely, as we have found no evidence of settled juveniles in deeper water at 2 unvegetated sites within Swan Bay; sampled with 3 replicate seines each month over 2 years (Jenkins \& May, unpublished data). This pattern suggests that although settlement may have been continuous, there was variability in space. Spatial variability in settlement may be due to patchiness of larvae due to disjunct spawning areas, non-random transport processes and planktonic mortality. Jenkins (1986) found that fish larvae in Port Phillip Bay, including Rhombosolea tapirina, occurred in multispecies patches associated with high abundances of zooplankton. Alternatively, spatial variability in settlement may be due to habitat selection at settlement.

Comparing back-calculated settlement of fish collected during the settlement season with those collected at the end of the season revealed a similar pattern of continuous settlement, but the 2 major cohort peaks were no longer present. Three hypotheses may account for this. One hypothesis is that the effects of density-dependent, post-settlement mortality may have modified the settlement patterns (Victor 1986). Veer (1986) showed that in early post-larval plaice
Pleuronectes platessa mortality may depend on the abundances of the plaice. Secondly, horizontal mixing along the foreshore may have caused the overall abundances between settlement areas to average over time. Thirdly, because settlement peaks were not pronounced, density independent, but highly variable mortality in time, may have obscured the settlement patterns.

\section{Growth}

Although the overall growth rate of Rhombosolea tapirina determined from size at age was $0.29 \mathrm{~mm} \mathrm{~d}^{-1}$. there appeared to be a slight increase in growth rate with increasing age after settlement, perhaps due to the effect of increasing water temperature. The growth rate of juveniles less than $20 \mathrm{~mm}$ SL was equal to the growth rate of $0.23 \mathrm{~mm} \mathrm{~d}^{-1}$ recorded for larval $R$. tapirina in Port Phillip Bay in the late flexion stage (Jenkins 1987). Larval growth of $R$. tapirina is exponential, ranging from 0.1 to $0.23 \mathrm{~mm} \mathrm{~d}^{-1}$ (Jenkins 1987), in contrast to the linear growth of juvenile flounder in Swan Bay.

Like juveniles collected in this study, pre-metamorphic larvae of Rhombosolea tapirina show a direct relationship between otolith size and fish size (Jenkins 1987). Analysis of the relationship between sagittal radius and standard length of larvae produces a significant linear regression $(\mathrm{n}=152, F=826.21, \mathrm{p}<0.001)$; however the rate of otolith growth relative to growth in standard length ( $\mathrm{SL}=0.160 \mathrm{R}+1.162$ ) was considerably slower in the larval stage. On the basis of the difference in growth rate between the larval and juvenile stages, otoliths of larvae should grow faster relative to standard length than otoliths of juveniles (Mosegaard et al. 1988, Secor \& Dean 1989). Our results, however, show that larvae had slower otolith growth relative to standard length. It is evident that the difference in the otolith growth rate relative to standard length between the 2 stages has a fundamental physiological basis not simply related to growth rate.

An inflection in the relationship occurs in the stage of metamorphosis, apparently the otolith continued to grow during this phase while growth in length was minimal. Larvae at this stage were generally Stage 5 and the transition zone was apparent at the edge of the otolith. This period of minimal growth in standard length was also evident in metamorphosing larvae collected by Jenkins (1987). A cessation of growth in length during metamorphosis is characteristic of flounders (Policansky 1982, Rosenberg \& Laroche 1982).

The regression method of back-calculation used in this study would give similar results to the biological intercept, Fraser-Lee method suggested by Campana (1990). This is because the regression intercept is very 
close to the biological intercept (Jenkins 1987), and mean size-at-age was utilised for analysis rather than individual values (Campana 1990).

Daily maximum air temperature was found to be correlated with daily growth, even though the air temperature would imperfectly reflect water temperature. Presumably, if water temperature data were available, correlations would be more significant. This result corresponds with a number of studies documenting the influence of temperature on the widths of daily growth increments (Neilson \& Geen 1982, Gutiérrez \& Morales-Nin 1986) but contrasts with that of Thorrold \& Williams (1989).

For the winter cohort, growth was positively correlated to a change in temperature after $2 \mathrm{~d}$. It is most likely that variation in temperature influenced metabolic rate, which in turn influenced both somatic and otolith growth (Marshall \& Parker 1982). The result for the winter cohort was very similar to that for Dicentrarchus labrax reared in the laboratory (Gutiérrez \& Morales-Nin 1986). The lagged effect of temperature change and its influence on growth over a number of days for the winter cohort suggests a conservative response of otolith growth to temperature variation (Gutiérrez \& Morales-Nin 1986), although the lagged effect of temperature may be partially due to a lag between change in air temperature and change in water temperature.

In contrast to the winter cohort, growth of the spring cohort was negatively correlated with temperature, the response was relatively rapid and only influenced growth on $1 \mathrm{~d}$. Decreased growth could be explained by an optimum temperature for growth in Rhombosolea tapirina; decreased growth may occur during periods of extreme high temperature, as high temperatures are likely to have a deleterious effect on physiological processes, such as metabolism. Such optima have been reported for other species (Boehlert 1981, Warlen 1987). A possible scenario to explain the results for the spring cohort might be that unusually hot days lead to a major disruption to metabolism, however normal metabolism is quickly restored when temperature returns to normal. The increased temperature towards summer may be the cause of juveniles moving to deeper water (Crawford 1984).

An alternative explanation may be that food became limiting at higher temperatures, although this should lead to a plateau in growth rather than a decrease at higher temperatures. It is possible that higher temperatures may have reduced the foraging ability of flounder, or decreased the availability of prey. Food availability had a marked affect on the growth of juvenile Pleuronectes platessa (Karakiri et al. 1989). Future research on the growth of juvenile $R$. tapirina will be directed at monitoring growth rates at different sites at a constant temperature, and concurrently determining food availability and production.

Acknowledgements. We thank Drs G. F. Watson and R. W. Day for commenting on drafts of the manuscript. This work was undertaken as part of the requirements for a B.Sc. (Hons.) degree to H. May from the University of Melbourne. Funding was provided by the Fishing Industry Research and Development Council.

\section{LITERATURE CITED}

Berghahn, R., Karakiri, M. (1990). Experimental induction of biological tags in otoliths of 0-group plaice Pleuronectes platessa by starvation, temperature, and UV-B radiation. Mar. Ecol. Prog. Ser. 67: 227-233

Boehlert, G.W. (1981). The effects of photoperiod and temperature on laboratory growth of juvenile Sebastes diploproa and a comparison with growth in the field. Fish. Bull. U.S. 79: 789-794

Brothers, E. B., MacFarland W. N. (1981). Correlations between otolith microstructure, growth and life history transitions in newly recruited French grunts [Haemulon lavolineatum (Desmarest), Haemulidae]. Rapp. P.-v. Réun. Cons. int. Explor. Mer 178: 369-374

Campana, S. E. (1984). Microstructural growth patterns in the otoliths of larval and juvenile starry flounder, Platichthys stellatus. Can. J. Zool. 62: 1507-1512

Campana, S. E. (1990). How reliable are growth backcalculations based on otoliths? Can. J. Fish. Aquat. Sci. 47: 2219-2227

Campana, S. E., Gagné, J. A., Munro, J. 1987. Otolith microstructure of larval herring (Clupea harengus): image or reality? Can. J. Fish. Aquat. Sci. 44: 1922-1929

Campana, S. E., Neilson, J. D. (1985). Microstructure of fish otoliths. Can. J. Fish. Aquat. Sci. 42: 1014-1032

Crawford, C. M. (1984). An ecological study of Tasmanian flounder. Ph.D. thesis. Univ. of Tasmania

Doherty, P. J., Williams, D. McB. (1988). The replenishment of coral reef fish populations. Oceanogr. mar. Biol. A. Rev. 26: $487-551$

Gutiérrez, E., Morales-Nin, B. (1986). Time series analysis of daily growth increments in Dicentrarchus labrax L. otoliths. J. exp. mar. Biol. Ecol. 103: 163-179

Hutchins, B., Swainston, R. (1986). Sea fishes of Southern Australia. Swainston Publishing, Perth

Jenkins, G. P. (1986). Composition, seasonality and distribution of ichthyoplankton in Port Phillip Bay, Victoria. Aust. J. mar. Freshwater Res. 37: 507-520

Jenkins, G. P. (1987). Age and growth of co-occurring larvae of two flounder species, Rhombosolea tapirina and Ammotretis rostratus. Mar. Biol. 95: 157-166

Jenkins, G. P., Davis, T. L. O. (1990). Age, growth rate, and growth trajectory determined from otolith microstructure of southern bluefin tuna, Thunnus maccoyii, larvae. Mar. Ecol. Prog. Ser. 63: 93-104

Jones, C. (1986). Determining age of larval fish with the otolith increment technique. Fish. Bull. U.S. 84: 91-103

Karakiri, M., Berghahn, R., Westernhagen, H. von (1989). Growth differences in 0-group Pleuronectes platessa as revealed by otolith microstructure analysis. Mar. Ecol. Prog. Ser. 55: 15-22 
Keough, M. J., Downes, B. J. (1982). Recruitment of marine invertebrates: the role of active larval choices and early mortality. Oecologia 54: 348-352

Kurth, D. (1957). An investigation of the greenback flounder. (Rhombosolea tapirina, Günther). Ph.D. thesis, Univ. of Tasmania

Marshall, S. L., Parker, S. S. (1982). Pattern identification in the microstructure of sockeye salmon (Oncorhynchus nerka) otoliths. Can. J. Fish. Aquat. Sci. 39: 542-547

Mosegaard, H., Svedang, H., Taberman, K. (1988). Uncoupling of somatic and otolith growth rates in Arctic char (Salvelinus alpinus) as an effect of differences in temperature response. Can. J. Fish. Aquat. Sci. 45: 1514-1524

Neilson, J. D., Geen, G. H. (1982). Otoliths of chinook salmon (Oncorhynchus tshawytscha) daily growth increments and factors influencing their production. Can. J. Fish. Aquat. Sci. 39: 1340-1347

Panella, G. (1971). Fish otoliths: daily growth layers and periodical patterns. Science 173: 1124-1127

Policansky, D. (1982). Influence of age, size and temperature on metamorphosis in the starry flounder, Platichthys stellatus. Can. J. Fish. Aquat. Sci. 39: 514-517

Rijnsdorp, A. D., van Stralen, M., Veer, H. W. van der (1985). Selective tidal transport of North Sea plaice larvae Pleuronectes platessa in coastal nursery areas. Trans. Am. Fish. Soc. 114: 461-470

Rosenberg, A. A., Laroche, J. L. (1982). Growth during metamorphosis of English sole, Parophrys vetulus. Fish Bull. U.S. 80: $150-153$

Ryland, J. S. (1966). Observations on the development of larvae of the plaice, Pleuronectes platessa L., in aquaria. J. Cons. perm. int. Explor. Mer 30: 177-195

Secor, D. H., Dean, J. M. (1989). Somatic growth effects on the otolith fish-size relationship in young pond-reared striped

This article was submitted to the editor bass (Morone saxatilis). Can. J. Fish. Aquat. Sci. 46: 113-121

Smith, P. E. (1985). Year-class strength and survival of 0group clupeoides. Can. J. Fish. Aquat. Sci. 42: 69-82

Stewart, B. D., Jenkins, G. P. (1991). Daily growth increments in the otoliths of juvenile greenback flounder, Rhombosolea tapirina Gunther, 1862. J. Fish. Biol. 39: 605-608

Thompson, M. (1990). Growth rates of juvenile flounder, Rhombosolea tapirina, in relation to food availability and temperature: a comparison between Swan Bay and nearby sites in Port Phillip Bay. B.Sc. (Hons.) thesis, Univ. of Melbourne

Thorrold, S. R., Williams, D. McB. (1989). Analysis of otolith microstructure to determine growth histories in larval cohorts of a tropical herring (Herklotsichthys castelnaui). Can. J. Fish. Aquat. Sci. 46: 1615-1624

Veer, H. W. van der (1986). Immigration, settlement and density dependent mortality of a larval and early post larval 0-group plaice (Pleuronectes platessa) population on the Western Wadden Sea. Mar. Ecol. Prog. Ser. 29: 223-236

Victor, B. C. (1983). Settlement and larval metamorphosis produce distinct marks on the otoliths of the slippery dick, Halichoeres bivittatus. In: Reaka, M. L. (ed.) The ecology of deep and shallow reefs. Office of Undersea Research, U.S. Department of Commerce, Washington, D.C., p. 47-52

Victor, B. C. (1986). Larval settlement and juvenile mortality in a recruitment-limited coral reef fish population. Ecol. Monogr. 56: 145-160

Warlen, S. M. (1987). Age and growth of larval gulf menhaden (Brevoortia patronus), in the Northern Gulf of Mexico. Fish. Bull. U.S, 86: 77-90

Wilkinson, L. (1987). SYSTAT: the system for statistics. SYSTAT Inc, Evanston, Illinois

Manuscript first received: June 13, 1991

Revised version accepted: December 30, 1991 